\title{
Exploring Customer Dissatisfaction/Satisfaction and Complaining Responses among Bank Customers in Ghana
}

\author{
Simon Gyasi Nimako ${ }^{1} \&$ Anthony Freeman Mensah ${ }^{1}$ \\ ${ }^{1}$ Department of Management Studies Education, University of Education, Ghana \\ Correspondence: Simon Gyasi Nimako, Department of Management Studies Education, University of Education, \\ Winneba, Kumasi Campus, Box 1277, Kumasi, Ghana. E-mail: sim.ekomerce@gmail.com.
}

$\begin{aligned} & \text { Received: December 31, } 2013 \\ & \text { Accepted: January 27, } 2014 \quad \text { Online Published: March 24, } 2014 \\ & \text { doi:10.5539/ijms.v6n2p58 }\end{aligned} \quad$ URL: http://dx.doi.org/10.5539/ijms.v6n2p58

\begin{abstract}
The paper explores the relationship between customer dissatisfaction/satisfaction and complaining responses among bank customers in Ghana banking industry. The study was a cross-sectional survey that used a self-administered structured questionnaire to collect primary data from 448 customers from ten selected banks in Ghana. The findings are that, though dissatisfaction causes customer complaining, dissatisfaction was more prevalent among non-complainers than complainers. Again, frequency of complaining is more likely to increase overall satisfaction if managed effectively. The most likely to be used complaining responses are complaining in person and refraining from using the bank's services, while the least likely to be used complaining responses are complaining to the mass media and consumer associations. Moreover, public bank customers are more likely to complain by refraining from using the bank's services and warning family and friends than private bank customers do. There was significant correlation between complaining responses and frequency of complaining, and between complaining responses and overall satisfaction. Theoretical and managerial implications are discussed. In spite of its limitations, the paper contributes to the body of knowledge in the area of consumer complaining behaviour in banking industry in emerging economies.
\end{abstract}

Keywords: dissatisfaction, complaining frequency, overall satisfaction, complaining responses, banking industry, Ghana

\section{Introduction}

The customer-centric marketing philosophy is undoubtedly found to be critical for business organizations' long-term survival and growth (Kotler \& Keller, 2006; Gronroos, 1994; Stone, Woodcock, \& Macthynger, 2000). This has resulted in development and implementation of business strategies that seek to understand customers better in order to satisfy and retain them for the organization (Kotler \& Keller, 2006; Gronroos, 1994). Such strategies focus on areas such as customer relationship management, customer complaint management, customer satisfaction surveys, among others. In complaint management, marketers make purposeful attempt to understand customer complaint behaviour (CCB) in order to provide effective solutions to their problems. CCB, therefore, is one area that has received great deal of attention from practitioners and scholars in the marketing literature.

Many past studies have found that CCB is significantly caused by customer satisfaction/dissatisfaction, and that dissatisfied customers are more likely to complain than satisfied customers (Heung \& Lam, 2003; Maute \& Forrester, 1993; Mowen, 1993). Despite the effort banking service providers make towards providing excellent service quality for achieving satisfaction and loyalty, the fact still remains that "No organization is so perfect in the delivery of superior customer performance that significant levels of dissatisfaction (the source of complaints) do not exist" (Wysocki, Kepner, \& Glasser, 2001, p. 1). Research has established that even some satisfied customers may still complain in order to provide useful feedback to product/service providers on service quality (Liu, Kang, Bai, \& Zhang, 2006).

Moreover, some dissatisfied customers may not voice their complaint to the product/service provider, but may use other avenues to complain such as negative word-of-mouth, aggression, taking the business to a competitor elsewhere, among others (Cheng, Lam, \& Hsu, 2006; Cho et al., 2002; Wysocki, Kepner, \& Glasser, 2001). Furthermore, the frequent personal interactions involved in banking services between banking staff and customers make it more crucial to understand the responses consumers use to complain about banking services, especially in emerging economies. 
On the one hand, research in CCB in the African context in general and Ghana in particular is very scanty. Few of those that exist focus on the mobile telephony industry (e.g., Mensah, 2012; Nimako \& Mensah, 2012, Nimako, 2012). Much of the empirical research on CCB focused on American, European, and Asian consumers (Bunker \& Bradley, 2007; Heung \& Lam, 2003; Huefner \& Hunt, 2000; Johnston, 1998; Lerman, 2006; Liu \& McClure, 2001; Stephens \& Gwinner, 1998; Velazquez, Blasco, Saura, \& Contri, 2010; Voorhees, Brady, \& Horowitz, 2006). Very little is known regarding consumer complaining towards banking services in the emerging country perspective. This calls for more empirical research in CCB in the banking service sector to increase our understanding of CCB in developing country context and within the African and Ghanaian context, in particular.

On the other hand, given that dissatisfaction could seriously induce many negative customer behaviour such as customer switching, customer aggression, negative word-of-mouth and public complaints through the media (Cheng, Lam, \& Hsu, 2006; Liu, Kang, Bai, \& Zhang, 2006; Cho et al., 2002; Nimako, 2012; Mensah, 2012), it becomes critically important for management of banks in Ghana to understand customer satisfaction/dissatisfaction and how it leads to various complaining responses among bank customers. Moreover, there is acute empirical research on the how complaining responses or channels are theoretically related to complaining frequency and overall satisfaction in the banking industry in general and in Ghaan in particular. More research is needed in this area to contribute to the theoretical debate on the links between complaining behaviour and overall satisfaction of customers. Therefore, the main purpose of this paper is to explore the relationship between dissatisfaction/satisfaction and complaining responses towards banking services among Ghanaian consumers. Specifically, the study is guided by the following objectives:

1) To examine satisfaction/dissatisfaction among complainers and non-complainers in the Ghana's banking industry.

2) To assess the influence of frequency of complaining on overall satisfaction.

3) To identify and prioritise customer complaint responses

4) To determine the differences in complaining response in private and public banks

5) To determine the correlation between complaining frequency and responses, and between complaining responses and overall satisfaction.

The paper continues with a review of existing literature on CCB. It is followed by the methodology of the empirical investigation and discussion of findings. Finally, the theoretical, strategic and policy implications are discussed.

\section{Literature Review and Hypothesis}

\subsection{The Concept of Customer Complaining Behaviour (CCB)}

The concept of CCB has received considerable attention among scholars in the literature. Jacoby and Jaccard (1981) define it as "An action taken by an individual which involves communicating something negative regarding a product or service either to the firm manufacturing or marketing that product or service or to some third-party organizational entity." According to Mowen (1993), complaint behaviour is any one of a number of actions that is triggered by perceived dissatisfaction with a purchase episode. It is a process which "constitutes a subset of all possible responses to perceived dissatisfaction around a purchase episode, during consumption or during possession of the goods or services" (Crie', 2003, p. 62).

These definitions suggest that complaint may arise as a result of defective or poor product or service quality, unfulfilled expectations in the service encounter, or some unfulfilled promises given by the product manufacturer or service provider. Customers may complain about some attribute of a product or dimension of service quality that is perceived as dissatisfactory. Complaint may also result from dissatisfaction during the purchase, possession or consumption of a product/service. Thus, in banking services context complaint may be made by customers about the bank charges and rates, long waiting period, poor customer service, poor network banking system quality, service failures, not keeping promises, among other things.

\subsection{Strategic Importance of Customer Complaints}

There are several strategic benefits of consumer complaint behaviour. According to Dacin and Davidow (1997), consumers who voice their complaints offer more benefits to companies than those who do not as voicing complaints provides an opportunity for firms to manage complaints and retain their customers. According to Plymire (1991), the surest road to a customer-focused culture is through increased complaints. Customer complaints to the firm serve as useful feedback for service improvement. Again, complaints give opportunity to dissatisfied consumers to vent their unhappiness (Kowalski, 1996; Richins, 1983). It also creates opportunity to 
correct customer problems using service recovery strategies, which could affect overall customer satisfaction, trust, positive Word-of-Mouth communication, future re-purchases, and winning the confidence of once dissatisfied customers (Kau \& Loh, 2006; Tax, Brown, \& Chandrashekaran, 1998). Finally, complaints are a source of ideas for service/product re-design. Leaving customer complaints unattended to could be fatal. It has been found that poor complaining systems can lead to negative WOM communication about the service provider (Blodgett, Wakefield, \& Barnes, 1995). It therefore becomes critically important for service providers to welcome and encourage complaints from their customers, no matter the cost involved (Heung \& Lam, 2003).

\subsection{Theoretical Framework for Complaining Responses}

Several attempts in the marketing literature have been made to conceptualise the complaining behaviour phenomenon (Tronroll, 2012). This has resulted in several overlapping theoretical frameworks. One useful conceptualization of CCB responses was developed by Day and Landon (1976). In their CCB classification framework (Figure 1), the authors conceptualized CCB as a behaviour that is put forth, principally, in response to dissatisfaction, although it is admitted that dissatisfaction may not be a necessary condition for complaining (Jacoby \& Jaccard, 1981).

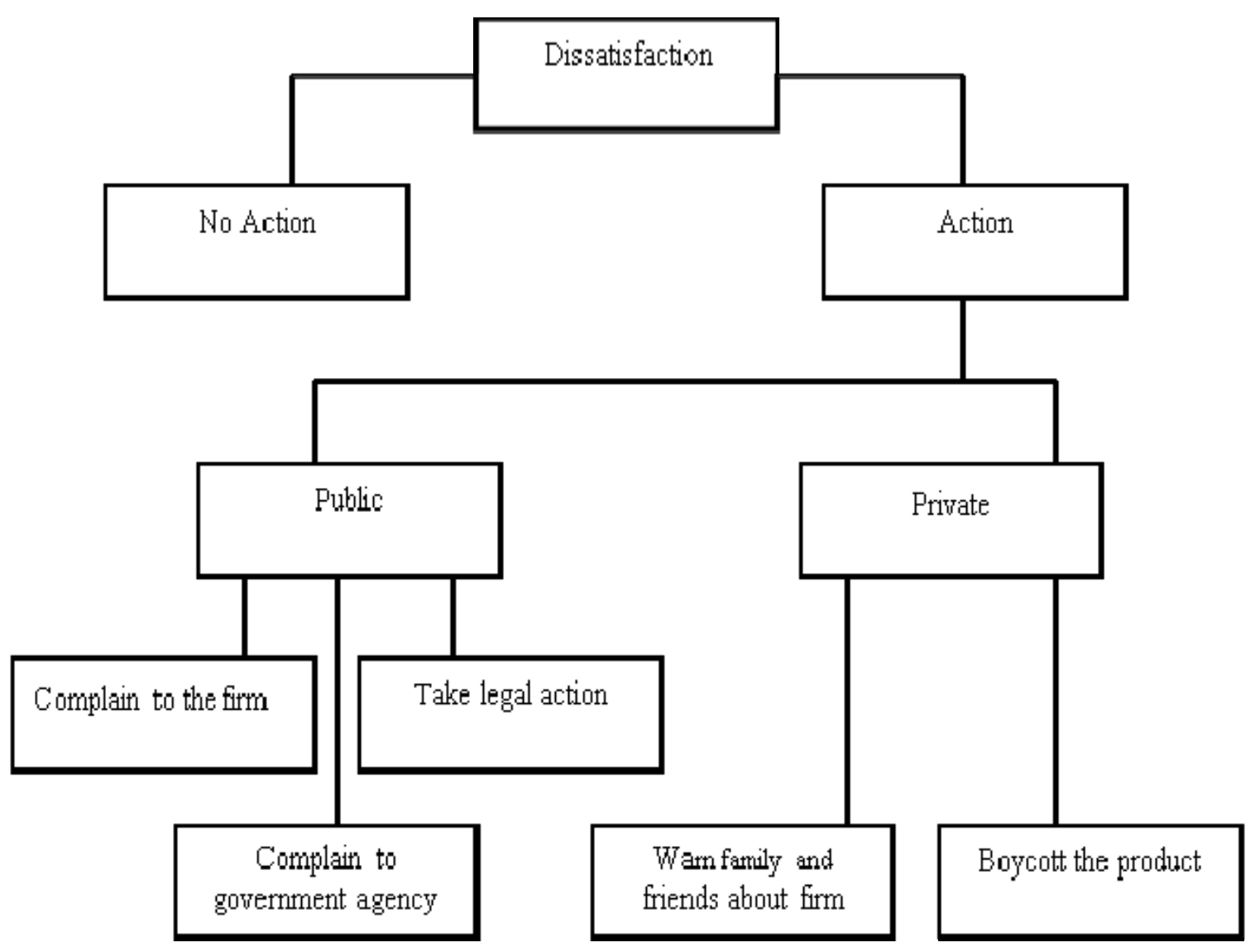

Figure 1. A classification of consumer complaining behaviour

Source: Day and Landon (1976).

\subsection{Satisfaction/Dissatisfaction and Complaining Responses}

The concept of CCB is strongly linked to customer dissatisfaction. Many studies confirm that dissatisfaction is the main cause of complaining (Liu \& McClure, 2001; Williams, Drake, \& Moran, 1993). This view has its roots in the expectancy disconfirmation theory (Oliver, 1980), that argues that dissatisfaction results from a discrepancy between customer expectation and perceived product/service performance. Since consumer expectation is found to be a major factor affecting consumers' evaluation of their purchase experiences (Day, 1977), it follows that, generally, consumers become dissatisfied when their expectations are not met by the current performance of a product or service. Consequently, they become disappointed and engage in complaining 
behaviour.

However, the term customer satisfaction (CS) may be viewed as Transactional or Cumulative. It is transactional-specific where CS is based on a one time, specific post-purchase evaluative judgement of a service encounter (Oliver, 1980, 1997). Conversely, it is cumulative where it involves an overall customer evaluation of a product or service based on purchase and consumption experiences over a time period (Fornell, 1992).

From the foregoing discussion, it is expected that a previous transactional satisfaction/dissatisfaction experience could result in complaining behaviour which could in turn influence the overall cumulative satisfaction rating of a service provider (Dacin \& Davidow, 1997; Kau, Richmond, \& Han, 1995). However, recent studies have shown that complaining beahaviour may not adversely influence overall satisfaction (Nimako, 2012; Mensah, 2012). Nimako (2012, p. 92) noted that "though previous dissatisfaction could affect customer overall satisfaction of a service provider, it may not always negatively affect overall satisfaction when it is properly managed by the service provider." Effective complaints management and service recovery systems are required to turn complainers into satisfied and loyal customers.

Again, the frequency of complaining may also influence the overall satisfaction of the customer with the service provider. In spite of the dearth of empirical research on how complaining channels are related to complaining frequency and overall satisfaction/dissatisfaction, there is some evidence that the more customers complain, the more it is likely to adversely affect their overall satisfaction of the service provider (Nimako, 2012; Mensah, 2012). When customers complain frequently it could affect their behavoural intention such as likelihood to recommend the firm as well as their intentions to switch to a competitor.

\subsection{Research Hypotheses}

Based on the literature reviewed, the following hypotheses are postulated for empirical testing:

H1: Previous transactional dissatisfaction will significantly differ among complainers and non-complainers towards banking services. Specifically, previous transactional dissatisfaction will be higher in complainers than non-complainers.

$\mathrm{H} 2$ : Overall satisfaction will significantly differ according to the frequency of complaining. Specifically, customers who complain more frequently will have lower overall satisfaction than those who complain less frequently.

H3: There is a significant correlation between complaining responses and frequency of complaining.

H4: There is a significant correlation between complaining responses and overall satisfaction.

\subsection{Overview of Ghana's Banking Industry}

According to the Ghana Banking Survey, currently there are 26 banks licensed to operate in Ghana (Ghana Banking Survey, 2013). The industry has experienced different levels of sophistication in banking activities with the introduction of ICT framework to facilitate the development of ICT in all sectors of the economy. With the emergence of many multi-national banks internationalizing into the Ghanaian banking industry and the development of electronic banking systems, competition in the industry has intensified. Many banks are now offering a variety of electronic products and transactions that allow customers to receive their monthly bank statements via e-mail, online checking of accounts balance, online transfer of funds, the use of electronic cash systems, and for communicating to customers regarding bank statements. Other banks use internet banking services to allow business customers to make inter-bank financial transactions and information sharing (Abor, 2011; Boateng, 2006; Woldie, Hinson, Iddrisu, \& Boateng, 2008).

According to the Ghana banking survey (2013), the banking industry in Ghana has been growing steadily in many respects over the past five years. The industry's total operating assets has increased by a remarkable $153 \%$ from 2009 to 2013, and total operating income has shown a steady increase even more significantly by $176 \%$ over the same period. However, the challenge for the industry will be sustaining the strong return on equity. This trend has been attributable to a growth in deposits and the cooperation of banks to meet the minimum capital requirement of the Bank of Ghana. The industry's assets are largely held in loans and advances, which formed $46 \%$ of operating assets in 2012. This in turn implied a drop in cash holdings by $4 \%$. Investments in liquid assets only declined by $1 \%$. From 2009, smaller banks appear to gain in market share partly because of their willingness to offer attractive rates on time and fixed deposits to attract deposits to invest in lending. The best increases in market share of operating assets were recorded by the banks which were involved in a business combination during the year.

Generally, deposits have been growing gradually, with currently average rates for time deposits over the period 
ranging from $7.8 \%$ and $12.5 \%$ in the past three years. This has been attributable to yield offered on government treasury bills. In spite of the attractive yields, customers continue to rely on banks to hold idle funds in banks because of the high transaction demand. The industry's net profits has steadily improved from $2.4 \%$ in 2011 to $3.5 \%$ in 2012. This profitability was largely driven by interest income earned on investment securities and the loan portfolio. Total assets grew by $28 \%$ in 2012 . Overall the industry shows a good operating performance for the year ended 31 December 2012.

As a result of the growth and intense competition in the Ghanaian banking industry, many banks are challenged to respond by focusing on satisfying customer needs and requirements in ways that would make them survive competition. In this regard, the use of customer service systems is prevalent among the financial institutions in the country. One area that the banks would benefit from most is to explore banking customers' complaining behaviour in order to deliver effective customer service, win more customers and keep profitable ones in the face of the intense competition.

\section{Methodology}

The study population consisted of individual customers of 10 selected banking institutions in Ghana: Ecobank Ghana, National Investment Bank, Ghana Commercial Bank, Bosomtwe Rural Bank, Societe-Generale Social Security Bank Ghana, Fidelity Bank, Atwima Nwabiagya Rural Bank, Barclays Bank, United Bank for Africa, and Agricultural Development Bank. These companies were chosen purposively because they represent a cross section of all the different banking institutions in terms of the banking products/services offered and electronic banking systems deployed. In the absence of a sampling frame, a convenient sampling technique was used to select a sample of 50 customers from each company, totalling 650 customers. In selecting the sample of 650 respondents, conscious effort was made to include only customers who have used the services of the companies for the past twelve months.

A self-administered, structured questionnaire was used to collect data from respondents. The questionnaire had only closed-ended question items and consisted of sections for customer satisfaction and complaining attitudes, complaining responses, and the respondents' characteristics. Respondents were asked to indicate whether they have ever complained or not, whether they have ever been dissatisfied with the services of their companies or not, using "Yes" and "No" responses. Satisfaction was measured on a five-point Likert scale from very dissatisfied to very satisfied.

Again, respondents were asked to indicate their agreement or disagreement to statements about the responses for complaining and non-complaining behaviour based on the work of Heung and Lam (2003). The questionnaire was pre- tested, refined and finally administered to the target sample through personal contact by the researcher. Informed consent information was attached to each questionnaire. 448 questionnaire representing $68.9 \%$ response rate was retrieved from the 650 questionnaire administered. Data were analysed using SPSS (version 16.0) for descriptive statistics, cross tabulation, and Kruskal-Wallis ANOVA that is more robust and suitable for analyzing differences between sub-groups involving categorical dependent variables.

\section{Data Analysis}

\subsection{Respondents' Characteristics}

The characteristics of the respondents for the study are presented in Table 1. Generally, it shows that, in terms of gender, there were more males (58.5\%) than females (41.5\%). Most of them were below the age of 35 years, followed by those within the ages of 36 and 45 years and few were above 45 years. In terms of education, most of them had tertiary education, followed by those with pre-tertiary (SHS and Post-SHS) while few had other types of education. For monthly income, most of the respondents earned up to US\$250, followed by those who earned between US\$250 and US\$500, about 3\% earned above US $\$ 500$. In term of marital status, about $51 \%$ of them were single, about $45.5 \%$ were married while the rest were in other marital categories. Finally, $57.6 \%$ of the respondents were customers of private banking institutions while $42.4 \%$ were customers of public banks in Ghana. 
Table 1. Respondents' characteristics

\begin{tabular}{|c|c|c|c|}
\hline Variable & Category & No. & $\%$ \\
\hline \multirow[t]{2}{*}{ Gender } & Male & 262 & 58.5 \\
\hline & Female & 186 & 41.5 \\
\hline \multirow[t]{5}{*}{ Age } & Below 25 & 93 & 20.8 \\
\hline & $25-35$ & 209 & 46.7 \\
\hline & $36-45$ & 110 & 24.6 \\
\hline & $46-55$ & 30 & 6.7 \\
\hline & $56+$ & 6 & 1.3 \\
\hline \multirow[t]{4}{*}{ Education Level } & SHS & 81 & 18.1 \\
\hline & Post SHS & 77 & 17.2 \\
\hline & Tertiary & 283 & 63.1 \\
\hline & Other & 7 & 1.6 \\
\hline \multirow[t]{5}{*}{ Income $(\mathrm{GH} \phi)$} & Below 100 & 50 & 11.2 \\
\hline & $101-500$ & 205 & 45.5 \\
\hline & $501-1000$ & 147 & 32.8 \\
\hline & $1001-1500$ & 34 & 7.6 \\
\hline & Above 1500 & 12 & 2.7 \\
\hline \multirow[t]{3}{*}{ Marital Status } & Married & 204 & 45.5 \\
\hline & Single & 229 & 51.1 \\
\hline & Other & 15 & 3.3 \\
\hline \multirow[t]{2}{*}{ Type of bank } & Private & 258 & 57.6 \\
\hline & Public & 190 & 42.4 \\
\hline
\end{tabular}

Note. $\mathrm{n}=448$.

\subsection{Customer Dissatisfaction and Complaining Behaviour}

The analysis of complainers and non-complainers and their previous dissatisfaction are presented in Table 2. It shows that $66.07 \%$ of customers complained for their previous transactional dissatisfaction and $33.93 \%$ of customers did not complain when dissatisfied. This suggests strongly that dissatisfaction causes customer complaints. Further analysis using Kruskal-Wallis ANOVA confirmed that previous dissatisfaction differed between complainers and non-complainers $\left(\mathrm{X}^{2}=61.253, \mathrm{df}=1, \mathrm{p}<0.001\right)$; more non-complainers experienced previous dissatisfaction (mean rank $=274.61)$ than complainers (mean rank $=198.77$ ). This implies that most non-complainers chose not to complain when dissatisfied with banking services.

Table 2. Dissatisfaction among complainers and non-complainers

\begin{tabular}{llllll}
\hline & & & \multicolumn{3}{c}{ Significant difference } \\
& Previous Dissatisfaction & Mean rank & $\mathbf{X}^{2}$ Value & df & Sign. \\
\hline Complainers & Yes $(\mathrm{n}=296) 66.07 \%$ & 198.77 & & & \\
Non-complainers & No $(\mathrm{n}=152) 33.93 \%$ & 274.61 & & & \\
Kruskal-Wallis ANOVA & & & 61.253 & 1 & 0.000 \\
\hline
\end{tabular}

\subsection{Frequency of Complaining and Overall Satisfaction}

In Table 3, Chi-square and Kruskal-Wallis analyses were conducted to test association and differences in overall satisfaction among different customer groups based on their complaining frequency. The analysis shows that overall satisfaction differs according to customers complaining frequency $\left(\mathrm{X}^{2}=12.372, \mathrm{df}=1, \mathrm{p}<0.05\right)$. Specifically, customers who were overall satisfied complained more (mean $=473.60)$ than those who were overall dissatisfied with banking services (mean $=420.38$ ). 
Table 3. Overall satisfaction among customers based on their complaining frequency

\begin{tabular}{|c|c|c|c|c|c|c|c|c|}
\hline \multirow[t]{2}{*}{$\begin{array}{l}\text { Overall } \\
\text { satisfaction }\end{array}$} & \multicolumn{5}{|c|}{ Complaining frequency } & \multicolumn{3}{|c|}{$\begin{array}{l}\text { K-Wallis tests of significant } \\
\text { difference }\end{array}$} \\
\hline & Once a while & Often & Very often & Always & Neutral & \multicolumn{3}{|c|}{ Mean ranks } \\
\hline Very dissatisfied & 23 & 12 & 14 & 4 & 7 & \multicolumn{3}{|c|}{$\begin{array}{l}\text { Not satisfied }=420.38 \\
\text { Neutral }=234.81\end{array}$} \\
\hline Dissatisfied & 24 & 25 & 14 & 10 & 19 & \multicolumn{3}{|c|}{ Satisfied $=473.6$} \\
\hline Neutral & 40 & 10 & 9 & 3 & 42 & & & \\
\hline Satisfied & 60 & 15 & 4 & 9 & 40 & & & \\
\hline Very satisfied & 22 & 0 & 4 & 4 & 34 & & & \\
\hline Total & 169 & 62 & 45 & 30 & 142 & & & \\
\hline \multicolumn{6}{|l|}{ Test of differences: } & $X^{2}$ Value & $d f$ & Sign. \\
\hline \multicolumn{6}{|l|}{ Pearson chi-square } & 78.234 & 16 & 0.000 \\
\hline \multicolumn{6}{|c|}{ Kruskal-Wallis ANOVA } & 12.372 & 4 & 0.015 \\
\hline
\end{tabular}

Note. Not satisfied includes dissatisfied and very dissatisfied; Satisfied includes very satisfied and satisfied customers.

\subsection{Prioritising Complaining Responses}

The study intended to find out the most used responses for customer complaining towards banking services. From Table 4, the analysis shows that, relatively, the most used complaining responses is complaining in person to the service provider by banking customers (mean=3.66). This is followed by refraining from using banking services outrightly (mean $=3.44)$, complaining by writing on compliant card (mean $=3.33$ ), complaining by writing complaint letters (mean=3.27), complaining by warning family and friends (mean=3.09), complaining to consumer group or association (mean= 2.73), and the least rated complaining channel used by banking customers is complaining to the mass media (mean $=2.43$ ).

Table 4. Prioritising complaining responses of banking customers

\begin{tabular}{|c|c|c|c|c|c|c|c|c|}
\hline \multirow[b]{2}{*}{ Rank } & \multirow[b]{2}{*}{ Complaining responses } & \multicolumn{2}{|c|}{ Full sample $(n=448)$} & \multirow{2}{*}{$\begin{array}{l}\begin{array}{l}\text { Public } \\
(n=190)\end{array} \\
\text { mean rank }\end{array}$} & \multirow{2}{*}{$\begin{array}{l}\begin{array}{l}\text { Private } \\
(n=258)\end{array} \\
\text { mean rank }\end{array}$} & \multicolumn{3}{|c|}{ K-Wallis test of differences } \\
\hline & & Mean & $\begin{array}{l}\text { Std. } \\
\text { Deviation }\end{array}$ & & & $\mathrm{X}^{2}$ & df & Sign. \\
\hline $1 \mathrm{st}$ & Complain in person & 3.662 & 0.979 & 229.35 & 220.93 & 0.53 & 1 & 0.466 \\
\hline 2nd & Stop using bank's services & 3.442 & 1.116 & 242.55 & 211.21 & 6.90 & 1 & $0.009 *$ \\
\hline $3 \mathrm{rd}$ & Writing on compliant card & 3.333 & 1.109 & 234.99 & 216.78 & 2.38 & 1 & 0.123 \\
\hline 4th & Writing complaint letters & 3.277 & 1.866 & 223.5 & 225.54 & 0.21 & 1 & 0.884 \\
\hline 5 th & Warn family and friends & 3.092 & 1.142 & 263.09 & 196.08 & 31.25 & 1 & $0.000^{*}$ \\
\hline 6th & $\begin{array}{l}\text { Complain to a consumer group or } \\
\text { association }\end{array}$ & 2.732 & 1.220 & 223.16 & 225.49 & 0.04 & 1 & 0.847 \\
\hline 7th & Complain to mass media & 2.438 & 1.112 & 223.29 & 225.39 & 0.03 & 1 & 0.861 \\
\hline
\end{tabular}

*significant at 0.01 ; scale — strongly disagree to strongly agree, coded 1-5.

Within public and private banks, the rankings of the complaining responses are relatively the same for first, third, fourth, sixth and seventh complaining responses. However, for the second and fifth generally ranked complaining responses, some differences exist between customers of public and private banks. Specifically, public bank customers are more likely to refrain from using the bank (mean rank= 242.55) and warning family and friends not to use the bank's services (mean rank= 263.09) than their counterparts in private banks.

\subsection{Linking Complaining Responses to Complaining Frequency and Overall Satisfaction}

The study sought to understand whether there is correlation between specific complaining responses and frequency of complaining as well the relationship between frequency of complaining and customers overall satisfaction with banking service providers. These relationships were examined using Pearson's correlation (r) analysis presented in Table 5 and the effect size analysis using shared variance between the two variables in 
question for the coefficient of determination $\left(\mathrm{R}^{2}\right)$. The amount of shared variance can be calculated by squaring the correlation coefficient (Pallant, 2011, p. 148). The size of the correlation coefficient can be interpreted using guidelines by Cohen (1988, pp. 79-81) which suggests the following guidelines: small $r=.10$ to .29 , medium $\mathrm{r}=.30$ to .49 , large $\mathrm{r}=.50$ to 1.0 .

\subsubsection{Complaining Responses and Complaining Frequency}

From the complaining channel-complaining frequency relationship in Table 5, complaining in person negatively correlates with complaining frequency $(\mathrm{r}=-.112, \mathrm{p}<0.05)$, implying that those who complain in persons do so less frequently. The $\mathrm{R}^{2}$ is 0.013 , implying that $1.3 \%$ of complaining in person could be attributable to customers who complain less frequently; this relationship could be described as weak and small effect (Cohen, 1988). Secondly, complaining by writing on a card has significant, negative correlation with frequency of complaining $(\mathrm{r}=-.134, \mathrm{p}<0.05)$, implying that those who complain by writing on a card do so less frequently. The $\mathrm{R}^{2}$ is 0.018 , implying that $1.8 \%$ of respondents' complaining by writing on card could be attributable to customers who complain less frequently; this relationship could be described as weak and small effect (Cohen, 1988).

Table 5. Correlation between complaining responses and complaining frequency, and overall satisfaction

\begin{tabular}{llllllllllll}
\hline S/N & Items & & SAT & COF & CIP & WFF & CMM & CCG & WCL & SUS & CWC \\
\hline SAT & Overall & R & 1 & $.13^{* *}$ & -0.01 & $-.19^{* *}$ & $-.17^{* *}$ & $-.12^{*}$ & -0.09 & $-.17^{* *}$ & -0.09 \\
& satisfaction/ & Sig. & & 0.007 & 0.813 & 0.000 & 0.000 & 0.011 & 0.053 & 0.000 & 0.051 \\
& dissatisfaction & & & & & & & & & & \\
\hline \multirow{2}{*}{ COF } & Complain & R & $.13^{* *}$ & 1 & $-.11^{*}$ & -0.07 & 0.09 & 0.02 & -0.01 & -0.06 & $-.13^{* *}$ \\
& frequency & Sig. & 0.007 & & 0.018 & 0.134 & 0.068 & 0.719 & 0.857 & 0.209 & 0.004 \\
\hline
\end{tabular}

Note. **. Correlation (R) is significant at the 0.01 level (2-tailed). *. Correlation (R) is significant at the 0.05 level (2-tailed). CIP complaining in person, WFF - warning family and friends, CMM - complaining to mass media, CCG - complaining to consumer group, WCL - writing complaint letters, SUS - stop using bank's services, and CWC - complaining by writing on a card.

\subsubsection{Complaining Frequency and Overall Satisfaction/Dissatisfaction}

From Table 5, complaining frequency positively correlates with overall satisfaction $(\mathrm{r}=.13, \mathrm{p}<0.05)$, implying that the more frequent banking customer complain about banking services the more they are likely to be satisfied with banking service provider. The $\mathrm{R}^{2}$ is 0.017 , implying that $1.7 \%$ of overall satisfaction with banking service provider could be attributable to frequency of complaining; this relationship could be described as weak and small effect (Cohen, 1988). This result confirms the previous analysis in Table 3 that there is a positive association between complaining frequency and overall satisfaction, implying that the more frequently customers complain the more they are likely to be overall satisfied with the bank service provider.

Moreover, the results in Table 5 indicate that overall satisfaction negatively correlates with warning family and friends $(\mathrm{r}=-.19, \mathrm{p}<0.05)$, complaining to mass media $(\mathrm{r}=-0.17, \mathrm{p}<0.05)$, complaining to consumer group $(\mathrm{r}=$ $-0.12, \mathrm{p}<0.05)$, and refraining from using the bank's services $(\mathrm{r}=-0.17, \mathrm{p}<0.05)$. This means that the more consumers warn family and friends, complain to mass media and consumer groups and think of refraining from using the bank's services, the more overall dissatisfied they are likely to be with a banking service provider.

\subsubsection{Results of Hypotheses}

Table 6. Results of hypothesis tests

\begin{tabular}{llr}
\hline Hypothesis & Specific directional hypothesis & Remarks \\
\hline H1 & Previous transactional dissatisfaction will be higher in complainers than non-complainers. & Not supported \\
H2 & Customers who complain more frequently will have lower overall satisfaction than those & Not supported \\
& who complain less frequently. & Supported \\
H3 & $\begin{array}{l}\text { There is a significant correlation between complaining responses and frequency of } \\
\text { complaining. }\end{array}$ & Supported \\
\hline
\end{tabular}

The results of hypotheses indicate that hypothesis $\mathrm{H} 1$ was not supported since the results showed that non-complainers had significantly more dissatisfaction than complainers. Similarly, hypothesis H2 was not 
supported since the results showed that customers who complain more frequently appeared to experience higher overall satisfaction than those who complained less frequently. Hypotheses H3 and H4 were supported since the results showed a significant correlation between responses and frequency of complaining, and a significant correlation between complaining responses and overall satisfaction.

\section{Discussion of Findings}

First, the results on satisfaction/dissatisfaction among complainers and non-complainers strongly suggest that dissatisfaction causes customer complaints (Table 2). This confirms what has been found in some previous studies that, generally, dissatisfaction causes customer complaints (e.g., Heung \& Lam, 2003; Maute \& Forreter, 1993).

However, results of hypothesis testing indicated that more non-complainers experienced previous dissatisfaction than complainers, implying that non-complainers chose not to complain when dissatisfied with banking services. This result did not provide support for hypothesis H1. While this finding contradicts some previous studies that claim that complaining is caused by dissatisfaction only (Liu \& McClure, 2001; Williams, Drake, \& Moran, 1993), it confirms other studies which found that some dissatisfied customers may not necessarily complain (Heung \& Lam, 2003; Maute \& Forreter, 1993). As the results indicated (Table 2), dissatisfaction was significantly greater in non-complainers than complainers. Such dissatisfied customers who do not complain are likely to switch to competitors and engage in negative Word-of-Mouth (WOM) communication to their immediate social groups. This is well supported by past empirical studies such as Blodgett et al. (1995) and Singh and Wilkes (1996). These findings in the banking services in Ghana also lend support to similar findings to previous research in complaining and non-complaining behaviour among customers of mobile telephony service providers (Nimako, 2012; Mensah, 2012; Nimako \& Mensah, 2012).

Second, the results (Table 3 ) on the influence of frequency of complaining on overall satisfaction indicate that customers of who were overall satisfied complained more than those who were overall dissatisfied with banking services. This implies that, generally, frequency of complaining influences overall satisfaction of banking customers. However, it did not provide empirical support for the hypothesis that customer who complain more frequently will have lower overall satisfaction than those who complain less frequently. The findings rather indicate that, the more frequently customers complain about banking services the more likely they are to be overall satisfied than dissatisfied with the banking service provider. While this finding appears contrary to some previous studies (Dacin \& Davidow, 1997; Kau, Richmond, \& Han, 1995), it strongly confirms current research findings that dissatisfaction incidents may not always negatively affect overall satisfaction if it is properly managed by the service provider (Nimako, 2012; Mensah, 2012; Nimako \& Mensah, 2012). In this regard, Nimako (2012, p. 92) noted that "though previous dissatisfaction could affect customer overall satisfaction of a service provider, it may not always negatively affect overall satisfaction when it is properly managed by the service provider." Thus, if previous dissatisfaction is managed effectively it could lead to positive outcomes of customer overall satisfaction with the banking service provider (Nyer, 2000).

Third, the results (Table 4) on the relative importance of customer complaint responses indicate that the most used complaining response is complaining in person to the service provider by banking customers, which is a voice response (Singh, 1990) and a public response (Day \& Landon, 1976). Complaining in person happens to be the highest rated complaining response for both public and private banking customers. In previous studies in mobile telephony industry in Ghana, complaining in person was found the most likely complaining response to be used by subscribers (Mensah, 2012; Nimako, 2012).

In the same way the second rated complaining response was refraining from using the banking service, being a private response (Day \& Landon, 1976), also received a second highest rated complaining response in the mobile telephony industry context (Mensah, 2012; Nimako, 2012). The third and fourth complaining responses are public responses, specifically, writing on complaining card and letters to banking service providers. This is followed by complain by warning family and friends. The two least rated complaining responses are complaining to consumer group or association and to the mass media, which are both public responses (Day \& Landon, 1976). These two least complaining responses were also found to be the least in complaining responses among mobile network subscribers (Mensah, 2012; Nimako, 2012).

One possible explanation for the respondents complaining to the mass media could be explained by the Ghanaian culture. Liu and McClure (2001) found that cultural difference may account for different complaining behaviour. Nimako (2012, p. 93) and Mensah (2012) shed some insight that, generally, Ghanaian customers are more reserved when it comes to making their complaints public. They appear to be characterized by a reserved attitude and let-me-keep-quiet attitude. They tend to be reluctant to complain to the mass media probably because they 
do not want their names to be mentioned in the public media for having reported a provider on service quality issues.

Fourth, the results indicate that customers of public and private banks in Ghana tend to exhibit similar complaining responses, except in two areas. Thus, comparing complaining responses between public and private bank customers, customers differed significantly on only two out of the seven complaining responses. These differences are likely to occur when it comes to responses such as boycotting the bank's services and warning family and friends from using the bank's services. Specifically, public bank customers are more likely to use these two response than private bank customers. One probable reason for this trend is that, in Ghana, most customer groups generally perceive public banks be less responsive and caring in terms of customers' needs and feelings than private banks. Therefore, customers tend to take action at the least dissatisfaction by either boycotting the bank's services and/or discouraging family and friends from using the bank's services. Thus, customers tend to perceive private banks to be more customer-focused than public banks. Also, these findings strongly suggest customer churn or switching is likely to be higher in public than in private banks, giving the private banks competitive urge over public banks in Ghana.

Fifth, results indicate that significant correlation exist between complaining frequency and responses, and between complaining responses and overall dissatisfaction, confirming hypotheses H3 and H4. More specifically, complaining in person and complaining by writing on card could be attributable to customers who complain less frequently, though the effect of the relationship appears to be weak and small. Also, results indicate that the more consumers warn family and friends, complain to mass media and consumer groups and refrain from using the bank's services, the more overall dissatisfied they are likely to be with a banking service provider.

\section{Theoretical Implications}

This paper offers some implications for marketing theory and practice. Tgeoretically, first, this study confirms previous studies that dissatisfaction causes complaints (Heung \& Lam, 2003; Maute \& Forreter, 1993). However, it provides new findings that dissatisfaction could be more prevalent among complainers than non-complainers. This suggests that most dissatisfied customers who do not complain are most likely to engage in negative word-of-mouth communication about the bank (Blodgett et al., 1995; Singh \& Wilkes, 1996). Similar to this finding, we also found that frequency of complaining did not necessarily lead to overall dissatisfaction. In fact, our findings are consistent with empirical findings that service failures if correctly rectified early often lead to positive reactions from customers (Bitner et al., 1990). In particular, our findings lend strong support to the fact that complaining can cause increased consumer satisfaction (Nyer, 2000). This further suggests that complaining could be an invaluable asset for companies to develop effective complaint management and service recovery systems that could turn dissatisfaction-caused complainers into overall satisfiers (McCollough, Berry, \& Yadav, 2000; Priluck \& Lala, 2009; Vos, Huitema, \& de Lange-Ros, 2008).

The study provides empirical evidence regarding the similarity of complaining responses among Ghana customers in industries such as banking and telecommunication. Thus, generally while Ghanaian customers seem to have the predisposition to complain in person and switch as the most likely complaining response, they also tend to use public complaining channels such as complaining to the mass media, consumer groups and writing letters as the last resort in exhibiting their complaint about some services including banking. One underlying reason for this behaviour is likely to be the influence of culture on complaining behaviour (Nimako, 2012, p. 93).

Another theoretical contribution is that the study provides empirical evidence that private and public banks' customers in Ghana may differ, at least, when it comes to complaining by boycotting bank's services and discouraging family and friends from using the bank's services. These complaining responses are likely to be higher in public bank customers than those in private banks. This could be explained by the generally lower customer-orientation perception about public banks in Ghana in the mind of the general public than it is in private banks.

Finally, the paper is among the first to explore the links between consumer complaining responses and overall satisfaction, and between complaining responses and frequency of complaining. It found that some complaining responses correlate significantly with overall dissatisfaction and complaining frequency.

\section{Managerial Implications}

The paper offers several implications and recommendations for management of banks. First, the study strongly confirms that dissatisfaction continue to be the main cause of customer complaint. Therefore, banking service providers need to make purposeful marketing attempts to discover the level of customer satisfaction and dissatisfaction in order to improve upon banking service delivery towards achieving customer satisfaction, 
delight and loyalty.

The study found that dissatisfaction was more prevalent among non-complainers than complainers. This means management of banks should strengthen their complaint management strategies in order to encourage customers to freely complain. Failure of customers to complain can be detrimental to service providers as such dissatisfied non-complainers are likely to engage in negative word-of-mouth communication and switch (Blodgett et al., 1995; Singh \& Wilkes, 1996; Mensah, 2012; Nimako, 2012).

One key finding was that transactional dissatisfaction and frequent complaining behaviour do not necessarily lead to overall dissatisfaction with the banking service provider. This implies that management of banks need to develop effective service recovery systems and innovative complaint management systems to manage complaints that are made known to the firm. In this way banking firms are able to develop and improve upon customer relationship management and achieve high customer life-time value, even among frequently complaining banking customers.

Moreover, since customers are likely to complain in person to the bank, it implies that management of banks should create a welcoming avenue for customers to complain in person. This could particularly be achieved by training customer service staff to be able to tactfully handle customers who complain in person. This require attitudes and skills such as patience, attentiveness, good interpersonal relationship, as well as attractive and welcoming dispositions.

Principally, the study implies that customer service in public banks in Ghana in particular needs more attention in order to manage customer complaints. Customer service is likely to be a key marketing strategy that public banks in Ghana needs to pay more attention in order to get more customers and retain existing profitable customers. Private banks should continue to use effective customer service to create favourable perception of the banks in the minds of customers as a strong positioning strategy and competitive advantage over the public banks in Ghana.

Finally, the findings imply that managers could detect consumer overall dissatisfaction with a bank by tracking it from certain types of customer complaining responses, such as customers warning family and friends, complaining to mass media and consumer groups, and treatening to stop using the bank's services. These consumer complaining responses could prove useful yardstick for detecting overall dissatisfaction of customers with a service provider in general and with a bank in particular.

\section{Limitations and Future Research}

Methodologically, interviews, focus groups and other projective techniques could be useful for improving upon the findings of our quantitative analysis in future research. This study appears to be limited to the use of structured survey instrument, which is only one data collection method. The research context also provides another limitation in that it focused on complaining behaviour in the Ghanaian banking industry in a B2C context, and not in a B2B context of institutional banking customers. Future research should extend complaining behaviour to different industry and customer contexts. Moreover, future research should examine the influence of culture on consumer complaining responses to further our theoretical understanding regarding cultural influences in consumer complaining behaviour.

\section{Conclusion}

In conclusion, the paper attempted to provide a descriptive analysis of customer dissatisfaction and complaining response in Ghana banking industry. It found that while dissatisfaction influences complaining, it is more prevalent in non-complainers than complainers. Moreover, frequency of complaining may not always lead to overall dissatisfaction if managed effectively by management of banks. The most mentioned complaining response is complaining in person, followed by boycotting the bank's services and the least rated is to make complain to the mass media and consumer groups. Finally, some complaining responses significantly correlate with overall satisfaction and frequency of complaining. The study is relevant to marketing theory and practices and offers suggestions on customer compplaints management, especially in the banking industry. Generalizations based on the findings of this study are limited and might not be applicable to every firm and industry context. Future research is recommended in the area of extending the study to other service and cultural contexts as well as examining the effects of service recovery on the relationship between complaining frequency and overall satisfaction/dissatisfaction of a service provider.

\section{References}

Abor, J. (2011). Technological innovations and banking in Ghana: An evaluation of customers' perceptions.

$$
\text { American Academy of Financial Management, 1, 1-16. Retrieved from }
$$


http://www.financialcertified.com/armstrong.html

Bitner, M. J., Booms, B. H., \& Tetreault, M. S. (1990). The service encounter: diagnosing favorable and unfavorable incidents. Journal of Marketing, 54, 71-84. http://dx.doi.org/10.2307/1252174

Blodgett, J. G., Wakefield, K. L., \& Barnes, J. H. (1995). The effects of customer service on consumer complaining behaviour. Journal of Services Marketing, 9(4), 31-42. http://dx.doi.org/10.1108/08876049510094487

Boateng, R. (2006). Developing E-banking Capabilities in a Ghanaian Bank: Preliminary Lessons. Journal of Internet Banking and Commerce, 11(2). Retrieved from http://www.arraydev.com/commerce/jibc/

Bunker, M. P., \& Bradley, M. S. (2007). Toward understanding customer powerlessness: analysis of an internetcomplaint site. Journal of Consumer Satisfaction, Dissatisfaction and Complaining Behaviour, 20, $54-71$.

Cheng, S., Lam, T., \& Hsu, C. H. C. (2006). Negative word-of-mouth communication intention: An application of the theory of planned behaviour. Journal of Hospitality and Tourism Research, 30(1), 95-116. http://dx.doi.org/10.1177/1096348005284269

Cho, Y., Im, I., Hiltz, R., \& Fjermestad, J. (2002). The Effects of Post-purchase Evaluation Factors of Online Vs. Offline Customer Complaining Behaviour: Implications for Customer Loyalty. Advances in Consumer Research, 29. Retrieved from web.njit.edu/ jerry/Research/Cho-ACR-2002.pdf

Cohen, J. (1988). Statistical Power Analysis for the Behavioral Sciences. HillsDale, NJ: Lawrence Erlbaum.

Crie', D. (2003). Consumers' complaint behaviour. Taxonomy, typology and determinants: towards a unified ontology. Journal of Database Marketing and Customer Strategy Management, 11(1), 60-79. http://dx.doi.org/10.1057/palgrave.dbm.3240206

Dacin, P. A., \& Davidow, M. (1997). Understanding and influencing consumer complaint behaviour: improving organizational complaint management. In Brucks, M., \& MacInnis, D. (Eds.), Advances in ConsumerResearch (Vol. 24, pp. 450-456). Association for Consumer Research, Provo, UT.

Day, R. L. (1977). Extending the concept of consumer satisfaction. Advances in Consumer Research, 4(1), $149-154$.

Day, R. L., \& Landon, L. (1976). Collecting comprehensive consumer complaint data by survey research. In Anderson, B. B. (Ed.), Advances in Consumer Research (vol. 3, pp. 263-268). Association for Consumer Research, Atlanta, GA.

Fornell, C. (1992). A National Customer Satisfaction Barometer: The Swedish Experience. Journal of Marketing, $56,6-21$.

Heung, V. C. S., \& Lam, T. (2003). Customer complaint behaviour towards hotel restaurant services. International Journal of Contemporary Hospitality Management, 15(5), 283-289. http://dx.doi.org/10.2307/1252129

Ghana Banking Survey. (2013). Retrieved December 12, 2013, from http://www.pwc.com/en_GH/gh/pdf/ghana-banking-survey-2013-pwc.pdf

Grönroos, C. (1994). From Marketing Mix to Relationship Marketing towards a Paradigm Shift Marketing. Asia Australia Marketing Journal, 2(1), 9-30. http://dx.doi.org/10.1016/S1320-1646(94)70275-6

Huefner, J. C., \& Hunt, H. K. (2000). Consumer retaliation as a response to dissatisfaction. Journal of Consumer Satisfaction, Dissatisfaction and Complaining Behaviour, 13, 61-82.

Jacoby, J., \& Jaccard, J. J. (1981). The Sources, Meaning, and Validity of Consumer Complaint Behaviour: A Psychological Analysis. Journal of Retailing, 57(3), 4-23.

Johnston, R. (1998). The effect of intensity of dissatisfaction on complaining behaviour. Journal of Consumer Satisfaction, Dissatisfaction and Complaining Behaviour, 11, 69-77.

Kau, K. A., \& Loh, E. W. Y. (2006). The effects of service recovery on consumer satisfaction: a comparison between complainants and non-complainants. The Journal of Services Marketing, 20(2), 101-11. http://dx.doi.org/10.1108/08876040610657039

Kau, K. A., Richmond, D., \& Han, S. (1995). Determinants of consumer complaint behaviour: a study of Singapore consumers. Journal of International Consumer Marketing, 8(2), 59-69. http://dx.doi.org/10.1300/J046v08n02_05 
Kotler, P., \& Keller, K. (2006). Marketing Management (12th ed.). New Jersey: Pearson Education Inc.

Kowalski, R. B. (1996). Complaints and complaining: functions, antecedents, and consequences. Psychological Bulletin, 119(2), 179-96. http://dx.doi.org/10.1037/0033-2909.119.2.179

Krapfel, R. E. (1985). A consumer complaint strategy model: antecedents and outcomes. Advances in Consumer Research, 12, 346-50.

Lerman, D. (2006). Consumer politeness and complaining behaviour. Journal of Services Marketing, 20(2), 92-100. http://dx.doi.org/10.1108/08876040610657020

Liu, J., Kang J., Bai, Y., \& Zhang, X. (2006). The Study Of Customer Complaints Management Based on System Dynamics: Modeling and Simulation. Proceedings of the Fifth International Conference on Machine Learning and Cybernetics, Dalian. Retrieved from http://ieeexplore.iee.org/stamp/stamp.jsp?arnumber $=04028400$

Liu, R. R., \& McClure, P. (2001). Recognising cross-cultural differences in consumer complaint behaviour and intentions: an empirical examination. The Journal of Consumer Marketing, 18(1), 54-75. http://dx.doi.org/10.1108/07363760110365813

Maute, M., \& Forrester, W. R. Jr. (1993). The Structure and Determinants of Complaint Intentions and Behaviour. Journal of Economic Psychology, 14, 219-247. http://dx.doi.org/10.1016/0167-4870(93)90001-2

McCollough, M. A., Berry, L. L., \& Yadav, M. S. (2000). An empirical investigation of customer satisfaction after service failure and recovery. Journal of Service Research, 3(2), 121-37. http://dx.doi.org/10.1177/109467050032002

Mensah, A. F. (2012). Customer complaint behaviour towards mobile telephony services-Cases of MTN and TIGO Ghana. International Journal of Business and Social Research, 2(4), 179-194.

Mowen, J. (1993). Consumer Behaviour. New York, NY: Macmillan Publishing Company.

Nimako, S. G. (2012). Customer Dissatisfaction and Complaining Behaviour towards Mobile Telephony Services in Ghana's mobile telephony Industry. African Journal ofInformation System, 4(3), 84-99.

Nimako, S. G., \& Mensah, A. F. (2012). Motivation for Complaining and Non-complaining Behaviour towards Mobile Telephony Services. Asian Journal of Business Management, 4(3), 310-320.

Nyer, P. U. (2000). An investigation into whether complaining can cause increased consumer satisfaction. Journal of Consumer Marketing, 17(1), 9-19. http://dx.doi.org/10.1108/07363760010309500

Oliver, R. L. (1980). A cognitive model of the antecedents and consequence of Customer Satisfaction. Journal of Marketing Research, 17, 460-469. http://dx.doi.org/10.2307/3150499

Oliver, R. L. (1997). Satisfaction: A Behavioural Perspective on the Consumer. NewYork, NY: The McGraw-Hill Companies.

Plymire, J. (1991). Complaints as opportunities. Journal of Consumer Marketing, 8(2), 39-43. http://dx.doi.org/10.1108/07363769110035009

Priluck, R., \& Lala, V. (2009). The impact of the recovery paradox on retailer-customer relationships. Managing Service Quality, 19(1), 42-59. http://dx.doi.org/10.1108/09604520910926809

Richins, M. L. (1983). Negative word-of-mouth by dissatisfied consumers: a pilot study. Journal of Marketing, 47, 68-78. http://dx.doi.org/10.2307/3203428

Singh, J. (1990). Identifying consumer dissatisfaction response styles: an agenda for future research. European Journal of Marketing, 24(6), 55-72. http://dx.doi.org/10.1108/03090569010140516

Singh, J., \& Wilkes, R. E. (1996). When consumers complain: a path analysis of the key antecedents of consumer complaint response estimates. Journal of the Academy of Marketing Science, 24(4), 350-74. http://dx.doi.org/10.1177/0092070396244006

Stephens, N., \& Gwinner, K. P. (1998). Why don't some people complain? A cognitive-emotive process model ofconsumer complaint behaviour. Journal of the Academy of Marketing Science, 26(3), 172-89. http://dx.doi.org/10.1177/0092070398263001

Stone, M., Woodcock, N., \& Macthynger, L. (2000). Customer Relationship Marketing: Get to you're your Customers and Win their Loyalty (2nd ed.). Great Britain Clays Ltd.

Tax, S. S., Brown, S. W., \& Chandrashekaran, M. (1998). Customer evaluations of service complaint experiences: 
implications for relationship marketing. Journal of Marketing, 62(2), 60-76. http://dx.doi.org/10.2307/1252161

The National Communications Authority Act 524. (1996). Accra: Assembly Press. Retrieved from http://www.nca.org.gh/index.php?option $=$ com_contentandview=articleandid=80andItemid $=27$

Tronroll, B. (2012). A dynamic model of customer complaining behaviour from the perspective of service-dominant logic. European Journal of Marketing, 46(1/2), 284-305. http://dx.doi.org/10.1108/03090561211189338

Velazquez, B. M., Blasco, M. F., Saura, I. G., \& Contri, G. B. (2010). Causes for complaining behaviour intentions: the moderator effect of previous customer experience of the restaurant. Journal of Services Marketing, 24(7), 532-545. http://dx.doi.org/10.1108/08876041011081087

Voorhees, C. M., Brady, M. K., \& Horowitz, D. M. (2006). A Voice From the Silent Masses: An ExploratoryandComparative Analysis of Non-complainers. Journal of the Academy of Marketing Science, 34, 514-527. http://dx.doi.org/10.1177/0092070306288762

Vos, J. F. J., Huitema, G. B., \& de Lange-Ros, E. (2008). How organisations can learn from complaints. The TQM Journal, 20(1), 8-17. http://dx.doi.org/10.1108/09544780810842866

Williams, T. D., Drake, M. F., \& Moran, J. III. (1993). Complaint behaviour, price and the patronized. International Journal of Retail and Distribution Management, 21(5), 3-9. http://dx.doi.org/10.1108/09590559310042305

Woldie, A., Hinson, R., Iddrisu, H., \& Boateng, R. (2008). Internet banking: an initial look at Ghanaian bank consumer perceptions. Banks and Bank Systems, 3(3), 35-46.

Wysocki, A. F., Kepner, K. W., \& Glasser, M. W. (2001). Customer Complaints and Types of Customers. Department of Food and Resource Economics, Florida Cooperative Extension Service. Institute of Food and Agricultural Sciences. Retrieved from http://edis.ifas.ufl.edu

\section{Copyrights}

Copyright for this article is retained by the author(s), with first publication rights granted to the journal.

This is an open-access article distributed under the terms and conditions of the Creative Commons Attribution license (http://creativecommons.org/licenses/by/3.0/). 